\title{
EVALUASI PENERAPAN SISTEM INFORMASI AKUNTANSI PENERIMAAN DAN PENGELUARAN KAS PADA PT. DAYA ANUGRAH MANDIRI
}

\author{
Brando Nofdi Pusung ${ }^{1}$, David P. E. Saerang ${ }^{2}$, Anneke Wangkar ${ }^{3}$ \\ ${ }^{12}$ Jurusan Akuntansi, Fakultas Ekonomi dan Bisnis, Universitas Sam Ratulangi, Jl. Kampus Bahu, Manado, \\ 95115, Indonesia \\ E-mail: brandokho97@gmail.com
}

\begin{abstract}
Every organization needs an information system to facilitate the activities that have been carried out planned and supervised to control the company's financial cash flow. The purpose of this study is to evaluate the accounting information system for cash receipts and disbursements and observe whether there is synchronization between the system and the existing application. The method used is a descriptive qualitative research method that research begins by collecting and observing all parts in information comes in its entirety and the details are then collaborated to get a result. The results showed that the accounting information system for cash receipts and disbursements at PT. Daya Anugrah Mandiri is quite good, although there are a few mistakes when inputting cash and consumers names, but they can fulfill important elements of the accounting information system that are human resources, equipment, forms or documents, records/notes, procedures, and reports. Cash receipts and disbursements procedures are set up and done best to avoid mistakes that might occur, so until now the accounting information system for cash receipts and disbursements of PT. Daya Anugrah Mandiri can be done effectively.
\end{abstract}

Keywords: evaluation; application; cash receipts; cash disbursement

\section{PENDAHULUAN}

Sistem Informasi Akuntansi (accounting information system) atau disingkat SIA adalah sistem informasi yang terkomputerisasi untuk mengelola data keuangan yang berhubungan dengan data transaksi dalam siklus akuntansi serta penyajiannya dalam bentuk laporan keuangan bagi manajemen perusahaan. Sistem informasi yang sengaja dibuat untuk mempermudah kegiatan atau hal-hal yang berkaitan dengan akuntansi. SIA memiliki manfaat yang baik dalam memberikan efisiensi waktu dan meningkatkan akurasi pencatatan serta pelaporan akuntansi. Bawiling (2015) menyatakan bahwa kas (cash) adalah aktiva lancar yang meliputi uang kertas/logam dan benda-benda lain yang dapat digunakan sebagai media tukar/alat pembayaran yang sah dan dapat diambil setiap saat.

Menurut Mulyadi (2013:3), sistem informasi akuntansi pengeluaran kas merupakan formulir catatan dan laporan yang dikoordinasikan sedemikan rupa untuk menyediakan informasi akuntansi keuangan yang dibutuhkan oleh manajemen untuk menentukan kebijakan dalam pengelolaan kinerja perusahaan. Menurut Apriani (2019:5), sistem informasi akuntansi penerimaan kas merupakan sistem pencatatan yang dirancang dalam melaksanakan kegiatan penerimaan kas yang berasal dari penjualan tunai atau pelunasan piutang.

Kalumata et al. (2017) menemukan bahwa dalam perusahaan terdapat sistem informasi akuntansi penjualan dan sistem penerimaan kas dimana sistem informasi akuntansi penjualan dan penerimaan kas merupakan salah satu sub sistem informasi akuntansi yang menunjukkan prosedur dalam melakukan kegiatan penjualan dan penerimaan kas dari hasil penjualan sehingga tindakan kecurangan terhadap penjualan dan penerimaan kas dapat dihindari. Mahayusa et al. (2017) menemukan bahwa sistem informasi akuntansi merupakan suatu sistem mencatat, mengumpulkan, mengklasifikasikan data atau informasi yang di 
hasilkan dari transaksi perusahaan data atau informasi tersebut selanjutnya dianalisis, didistribusikan, dikomunikasikan kepada pihak-pihak yang memerlukan.

PT. Daya Anugrah Mandiri merupakan perusahaan swasta yang ada di Manado dan bergerak dalam bidang penjualan eceran motor bermerek Honda. Banyak kegiatan yang terjadi di PT. Daya Anugrah Mandiri, dan perusahaan ini mengharuskan penggunaan sistem informasi akuntansi yang baik karena banyaknya transaksi yang menyebabkan adanya penerimaan dan operasional perusahaan yang menyebabkan pengeluaran kas. Masalah yang terjadi di PT Daya Anugrah Mandiri yaitu kurang tepatnya pemasukkan data untuk kode jenis motor baru sehingga memungkinkan kurangnya pengendalian atas penjualan motor tersebut, kurang tepatnya pemasukkan data konsumen sehingga memungkinkan data kas dari pihak penyewa menjadi tidak akurat khususnya untuk kebutuhan konsolidasi laporan keuangan akhir periode.

\section{TINJAUAN PUSTAKA}

Effendi (2013:1) mendefinisikan akuntansi sebagai proses pengidentifikasian, pengukuran, pencatatan, penggolongan, dan pengikhtisaran serta pelaporan informasi keuangan dalam ukuran moneter (uang) pada suatu perusahaan atau organisasi yang ditujukan kepada pihak-pihak yang berkepentingan dalam rangka pengambilan keputusan. Menurut Susanto (2013:8), sistem informasi akuntansi adalah kumpulan atau kelompok dari sub sistem, komponen, bagian apapun baik fisik/non fisik yang saling berhubungan satu dengan yang lainnya dan bekerja sama secara harmonis untuk mengolah data transaksi yang berkaitan dengan masalah keuangan menjadi informasi keuangan. Menurut Rudianto (2012:4), sistem informasi akuntansi adalah sistem informasi yang menghasilkan informasi keuangan kepada pihak-pihak yang berkepentingan mengenai aktivitas ekonomi dan kondisi suatu perusahaan.

Katili et al. (2017) menemukan bahwa kas adalah alat pembayaran tunai yang setiap saat dapat digunakan untuk membiayai berbagai macam kegiatan yang dilakukan oleh suatu lembaga, instansi, atau suatu perusahaan. Berbagai macam transaksi yang terjadi di suatu perusahaan merupakan penerimaan dan pengeluaran kas. Menurut Katili et al. (2017), agar pengeluaran dan penerimaan kas tersebut dapat dengan mudah dikelola, maka harus dicatat dalam suatu buku yang disebut buku kas.

Menurut Mulyadi (2016:2), sistem informasi akuntansi adalah organisasi formulir, catatan dan laporan yang dikoordinasi sedemikan rupa yang berfungsi untuk menyediakan informasi keuangan yang dibutuhkan oleh manajemen guna memudahkan pengelolaan perusahaan dimana sistem informasi akuntansi merupakan kumpulan sumber daya seperti: manusia dan peralatan yang mengubah data akuntansi menjadi informasi akuntansi yang dibutuhkan oleh para penggunanya. Menurut Sumarsan (2013:1), kas merupakan aset lancar yang paling likuid yang berarti dapat digunakan secara langsung untuk keperluan operasional perusahaan dimana kas terdiri dari uang tunai dan uang yang berada dalam rekening sebuah bank. Menurut Baridwan (2010:3), sistem akuntansi kas merupakan formulir-formulir, catatan-catatan, prosedur-prosedur, dan alat-alat yang digunakan untuk mengolah data mengenai usaha suatu kesatuan ekonomis dengan tujuan untuk menghasilkan umpan balik dalam bentuk laporan-laporan yang diperlukan oleh manajemen untuk mengawasi usahanya, dan bagi pihak-pihak lain yang berkepentingan seperti pemegang saham, kreditur, dan lembaga-lembaga pemerintah untuk menilai hasil operasi. Sistem kas terbagi menjadi 2 (dua) sistem, yaitu: (1) sistem akuntansi penerimaan kas; dan (2) sistem akuntansi pengeluaran kas. Zatalini dan Subaweh (2018) menemukan bahwa dalam sistem informasi akuntansi, akuntan perusahaan harus dapat mendesain dan menerapkan informasi akuntansi yang baik sistem untuk mengelola keuangan perusahaan. Sedangkan Arfianty (2020) menemukan bahwa sistem akuntansi merupakan alat yang penting bagi manajemen untuk menghasilkan aktivitas- 
aktivitas perusahaan atas rencana yang telah ditetapkan terlebih dahulu sehingga rencana tersebut dapat berjalan secara efektif, efisien dan terarah.

Menurut Mulyadi (2016:385), sistem akuntansi penerimaan kas adalah suatu catatan yang dibuat untuk melaksanakan kegiatan penerimaan uang dari penjualan tunai atau pelunasan piutang dimana uang tunai tersebut siap dan bebas digunakan untuk kegiatan umum perusahaan. Menurut Sujarweni (2015:96), sistem penerimaan kas adalah suatu prosedur catatan yang dibuat untuk melaksanakan penerimaan uang yang berasal dari berbagai macam sumber yaitu dari penjualan tunai, penjualan aset tetap, pinjaman, dan setoran modal baru. Menurut Soemarso (2014:450), pengeluaran kas adalah suatu transaksi yang menimbulkan berkurangnya saldo kas dan bank milik perusahaan yang diakibatkan adanya pembelian tunai, pembayaran utang maupun transaksi yang menyebabkan berkurangnya kas. Soemarso (2014:450) juga menjelaskan bahwa terdapat 2 (dua) sistem yang dapat digunakan dalam pengeluaran kas yaitu sistem pengeluaran kas dengan cek dan sistem pengeluaran kas dengan uang tunai melalui sistem dana kas kecil.

Menurut Azhar (2013:52), sistem informasi akuntansi adalah komponen-komponen yang saling berhubungan dan bekerja sama untuk mengumpulkan, memproses, menyimpan informasi untuk mendukung pengambilan keputusan koordinasi, pengendalian, dan untuk memberikan gambaran aktivitas didalam perusahaan. Aznerda (2015) menjelaskan bahwa penerimaan kas perusahaan berasal dari dua sumber utama, yaitu penerimaan kas dari penjualan tunai dan penerimaan kas dari piutang sedangkan sistem akuntansi pengeluaran kas adalah pembayaran kas dalam perusahaan dilakukan dengan menggunakan cek kecuali untuk pembayaran dalam jumlah kecil biasanya dilaksanakan melalui dana kas kecil.

\section{METODE PENELITIAN}

\subsection{Jenis dan sumber data}

Penelitian ini menggunakan pendekatan kualitatif dimana tujuan pendekatan ini adalah untuk membuat deskripsi, gambaran sistematis secara faktual dan akurat atas faktafakta, sifat-sifat serta hubungan antar fenomena yang diselidiki. Sumber data dalam penelitian ini adalah data primer.

\subsection{Metode analisis}

Metode analisis yang digunakan dalam penelitian ini adalah metode analisis deskriptif dimana dengan metode ini data yang diperoleh akan dianalisis guna mengetahui efektifitas penerapan sistem akuntansi penerimaan dan pengeluaran kas pada PT. Daya Anugrah Mandiri Cabang Manado, yaitu dengan mengkaji, memaparkan, menelaah, dan menjelaskan data-data yang diperoleh untuk mendapatkan gambaran yang jelas dan menyeluruh tentang penerapan sistem akuntansi penerimaan dan pengeluaran kas. Setelah mendapatkan gambaran tentang penerapan sistem infromasi akuntansi penerimaan dan pengeluaran kas pada PT Daya Anugrah Mandiri maka penelitian ini mengevaluasi, menganalisis pemisahan fungsi, serta menganalisis prosedur yang ada dengan membandingkan konsep dengan prakteknya sehingga menghasilkan bukti kajian.

\section{HASIL PENELITIAN DAN PEMBAHASAN}

\subsection{Hasil penelitian}

Sistem penerimaan kas. Berdasarkan observasi pada PT. Daya Anugrah Mandiri, maka ditemukan bahwa sistem akuntansi penerimaan kas di PT. Daya Anugrah Mandiri adalah berupa penjualan eceran motor merek Honda, menerima jasa reparasi motor, dan penjualan suku cadang. Fungsi yang terkait dalam sistem akuntansi penerimaan kas di PT Daya Anugrah Mandiri adalah sebagai berikut:

- Bagian pemasaran (marketing). Bagian ini bertugas untuk mempromosikan dan memperkenalkan eceran motor merek Honda dengan beberapan varian jenis. 
- Bagian kasir. Bagian ini bertugas untuk menerima uang dari konsumen, dan pemberian kuitansi sebagai tanda terima.

- Administrasi penjualan. Bagian ini bertugas untuk membuat tagihan ke pihak pembiayaan, memasukkan data pelanggan, dan membuat laporan kepada atasan (ADH).

- Administration Head (ADH). Bertanggung jawab terhadap proses operasional dan mengawasi kegiatan administrasi, kelengkapan data, pengecekan, pengarsipan dokumen, dan pemeriksaan seluruh dokumen administrasi.

- Kepala Cabang (Kacab). Berkewajiban untuk memberikan laporan kemajuan cabang kepada Direksi Pusat termasuk keuangannya.

Sistem pengeluaran kas. Sistem akuntansi pengeluaran kas pada PT. Daya Anugrah Mandiri diterapkan untuk mengendalikan dan mengawasi pembiayaan pembelian eceran motor di main dealer dan melakukan pembiayaan untuk pembelian suku cadang lainnya. Fungsi yang terkait dalam sistem akuntansi pengeluaran kas pada PT. Daya Anugrah Mandiri adalah sebagai berikut:

- Bagian kasir. Bagian ini bertugas untuk mengeluarkan atau memberikan uang kepada karyawan untuk keperluan dealer seperti, membeli alat bengkel, eceran motor yang ada di main dealer, dan keperluan lainnya.

- Administration Head. Bagian ini bertugas untuk menyetujui pengeluaran kas dan memberikan kuitansi pengeluaran atau bukti pengeluaran kas.

- Kepala Cabang (Kacab). Bagian ini bertugas untuk mengontrol semua kejadian yang terjadi di dealer dan membuat laporan ke pusat.

\subsection{Pembahasan}

Sistem informasi akuntansi penerimaan kas di PT. Daya Anugrah Mandiri. Unsurunsur sistem informasi akuntansi penerimaan kas yang ada di PT Daya Anugrah Mandiri yaitu bagian pemasaran, bagian kasir, Bagian administrasi penjualan, Administration Head $(A D H)$, dan Kepala Cabang (Kacab). Bagian kasir bertugas untuk mengatur semua kas masuk dan pendataan kas masuk untuk dilaporkan pada atasan. Fungsi bagian pemasaran dan fungsi administrasi penjualan bertugas untuk melakukan penjualan dan promosi kepada konsumen dan pendataan konsumen sehingga disetujui oleh pihak pembiayaan dan pihak dealer. Dokumen sistem informasi akuntansi penerimaan kas yang ada di PT. Daya Anugrah Mandiri meliputi sales order (SO), bukti penerimaan kas, dan kas besar. Berdasarkan dokumen sistem, maka dapat disimpulkan bahwa dokumen sistem informasi akuntansi penerimaan kas yang ada di PT. Daya Anugrah Mandiri masih cukup efektif. Walaupun secara teknis masih terdapat permasalahan dalam pemasukkan data sistem akan tetapi hal ini masih dapat dikendalikan dan dapat dikoreksi secara akuntansi.

Sistem informasi akuntansi pengeluaran kas di PT Daya Anugrah Mandiri. Unsurunsur sistem informasi akuntansi pengeluaran kas yang ada di PT. Daya Anugrah Mandiri yaitu bagian Kasir, Administration Head (ADH), dan Kepala Cabang. Sistem informasi akuntansi pengeluaran kas yang telah menerapkan fungsi pengendalian, fungsi kas, dan fungsi pemeriksaan interen. Bagian kasir berkaitan langsung dengan fungsi pengendalian dan pengawasan atas beberapa berkas yang berkaitan dengan kas. Fungsi akuntansi ditangani secara langsung oleh bagian kasir dan ADH yaitu melakukan pencatatan saat kas keluar sekaligus melakukan perhitungan atas jumlah kas yang dikeluarkan. Fungsi pemeriksaan interen berhubungan dengan ADH karena bertanggung jawab atas jumlah kas yang keluar. Dokumen yang digunakan dalam sistem informasi akuntansi pengeluaran kas di PT. Daya Anugrah Mandiri meliputi Bukti Pengeluaran Kas, Laporan Pembelian, Kuitansi, dan Laporan Kas Kecil, Laporan kas kecil di PT. Daya Anugrah Mandiri berisi rekapitulasi pengeluaran kas selama 1 bulan penuh. Dokumen pengeluaran kas di PT, Daya Anugrah Mandiri menggunakan kuitansi untuk pembelian bahan-bahan yang di perlukan dan cek untuk pembayaran melalui bank. Masalah Sistem Infromasi Akuntansi Pengeluaran Kas di 
PT Daya Anugrah Mandiri. Sistem informasi akuntansi pengeluaran kas di PT. Daya Anugrah Mandiri telah memiliki alur prosedur sehingga sistem pengeluaran kas telah efektif. Walaupun secara teknis masih terdapat permasalahan dalam prosedur pengeluaran kas akan tetapi hal ini masih dapat dikendalikan dan dapat dikoreksi secara akuntansi.

\section{KESIMPULAN DAN SARAN}

\subsection{Kesimpulan}

Berdasarkan pembahasan maka penelitian ini menyimpulkan bahwa penerapan sistem informasi akuntansi untuk penerimaan kas dan penerimaan kas di PT. Daya Anugrah Mandiri sudah baik. Hal ini dibuktikan dengan adanya struktur organisasi yang memisahkan tanggungjawab secara baik. Adanya struktur organisasi yang baik dapat menyebabkan efektifnya fungsi-fungsi akuntansi serta menjamin akurasi dan transparansi dokumendokumen pendukung. Dokumen-dokumen yang digunakan dalam PT. Daya Anugrah Mandiri memiliki tanggungjawab oleh bagian terkait dan telah dikerjakan secara teratur.

\subsection{Saran}

Berdasarkan penelitian yang telah dilakukan, maka saran penelitian ini adalah optimalisasi dan pengembangan fungsi yang terkait dengan sistem informasi akuntansi penerimaan kas dan pengeluaran kas. Pelaksanaan fungsi atas kegiatan penerimaan dan pengeluaran kas perlu memperhatikan ketelitian dan akurasi yang muncul akibat kesalahan teknis. Pihak manajemen cabang dari PT. Daya Anugrah Mandiri perlu menegaskan penerapan sistem dan prosedur atas penerimaan kas dan pengeluaran kas pada setiap lini dalam struktur organisasi guna meminimalisir kesalahan teknis yang mungkin muncul.

\section{DAFTAR PUSTAKA}

Apriani, N. (2019). Sistem akuntansi penerimaan kas, Buku 1, Edisi 4. Bandung: Lingga Jaya.

Arfianty. (2020). Analisis sistem informasi akuntansi pengeluaran kas pada PT. PLN (Persero) Rayon Kariango Kabupaten Pinrang. Economos: Jurnal Ekonomi dan Bisnis, 3(1), 10-16. https://jurnalpertanianumpar.com/index.php/economos/article/view/611

Azhar, S. (2013). Sistem informasi akuntansi, Buku 1, Edisi 1. Bandung: Lingga Jaya.

Aznerda. (2015). Evaluasi penerapan sistem informasi akuntansi penerimaan dan pengeluaran kas pada. PT Harapan Jaya Sentosa. Measurement: Jurnal Akuntansi, 9(2), 27-41. https://www.journal.unrika.ac.id/index.php/measurement/article/view/1017

Baridwan, Z. (2010). Sistem akuntansi kas, Buku 1, Edisi 5. Yogyakarta: Badan Penerbit Fakultas Ekonomi UGM.

Bawiling, C. (2015). Evaluasi penerapan sistem pengendalian internal pengeluaran kas pada Kantor Pengadilan Agama Tondano. Jurnal EMBA: Jurnal Riset Ekonomi, Manajemen, Bisnis dan Akuntansi, 3(3), 619-629. https://ejournal.unsrat.ac.id/index.php/emba/article/view/9533

Effendi, R. (2013). Prinsip-prinsip akuntansi berbasis SAK ETAP, Edisi Revisi. Jakarta: PT Raja Gravindo.

Kalumata, N., Nangoi, G., \& Lambey, R. (2017). Evaluasi pengendalian internal sistem informasi akuntansi penjualan dan penerimaan kas pada PT. Hasjrat Abadi Cabang Malalayang Manado. Going Concern: Jurnal Riset Akuntansi, 12(2), 1205-1215. https://doi.org/10.32400/gc.12.2.18650.2017

Katili, I., Morasa, J., \& Budiarso, N. (2017). Evaluasi penerapan sistem akuntansi penerimaan dan pengeluaran kas pada PT. Ciputra Internasional Cabang Manado. 


Going Concern: Jurnal Riset Akuntansi, 12(01), 180-186.

https://doi.org/10.32400/gc.12.01.17203.2017

Mahayusa, W., Yuniarta, G., \& Sinarwati, N. (2017). Evaluasi sistem informasi akuntansi atas prosedur penerimaan dan pengeluaran kas dana program bantuan operasional sekolah sebagai penyedia informasi pengendalian internal pada Sekolah Menengah Atas Negeri 1 Busungbiu Kabupaten Buleleng. JIMAT (Jurnal Ilmiah Mahasiswa Akuntansi) $8(2)$, $1-10$. https://ejournal.undiksha.ac.id/index.php/S1ak/article/view/11456

Mulyadi. (2013). Sistem akuntansi, Edisi 4. Jakarta: Salemba Empat.

Mulyadi. (2016). Sistem informasi akuntansi, Edisi 4. Jakarta: Salemba Empat.

Rudianto. (2012). Pengantar Akuntansi Konsep dan Teknik Penyesuaian, Adaptasi IFRS. Jakarta: Erlangga.

Soemarso, S. R. (2014). Akuntansi suatu pengantar, Buku 1, Edisi kelima. Jakarta: Salemba Empat.

Sujarweni, V. W. (2015). Sistem akuntansi.Yogyakarta: Pustaka Baru Press.

Sumarsan, T. (2013). Akuntansi dasar dan aplikasi bisnis., Jilid 1, Edisi 2. Jakarta: Indeks.

Susanto. (2013). Sistem informasi akuntansi, Edisi Pertama. Bandung: Lingga Jaya.

Zatalini, M. A., \& Subaweh, I. (2018). Analysis and design accounting information system of funding and financing at Koperasi Serba Usaha Syariah Baitul Maal Wat Tamwil Bakti Nurul Huda. Jurnal Ilmiah Ekonomi Bisnis, 23(3), 277-295. http://dx.doi.org/10.35760/eb.2018.v23i3.1835 